\title{
IMPACT OF THE COVID-19 PANDEMIC ON THE INDUSTRIAL SECTOR: IMPLICATIONS FOR ECONOMIC POLICY
}

\author{
Larysa Lebedeva ${ }^{1}$, Oleksandra Moskalenko ${ }^{2}$
}

\begin{abstract}
The COVID-19 pandemic had a major impact on the economy around the world, damaging many areas of daily life. The industrial sector has been affected by the effects of industrial closures, reduced economic activity, and disruptions in logistics and transportation. The damage caused by the crisis has not yet been specifically assessed, as the industrial sector was not the most affected by the pandemic compared to other sectors of the economy. The subject of the study is the industrial sector of Ukraine and the EU. The aim of the article is to assess the impact of the COVID-19 pandemic on industrial development in Ukraine and the EU, as well as to propose economic policy measures to achieve stabilization in the industrial sector. Since industry is the foundation of economic growth and development, it is necessary to assess the depth of its decline and find possible solutions to get out of the recession. The theoretical analysis of the article is based on recent work by scientists in the field of industrial development, as well as on the authors' developments assessing the impact of the COVID-19 pandemic on the economy. The COVID-19 pandemic created the following problems for Ukraine's economy and industry: a decrease in aggregate global demand and a decline in business activity, which led to lower prices on world commodity markets; strengthening of government regulation; raw-material orientation of Ukraine's exports and the significant dependence of industrial enterprises on world prices for raw materials; transport and logistics problems with raw material supply chains; lower business expectations and reduced investment due to significant uncertainty. The findings showed that the coronavirus crisis hit the industrial sectors mainly in April 2020, leading to a $16.1 \%$ decline in industrial production in Ukraine and an $18.6 \%$ decline in the EU. Such industries as automobile manufacturing, leather manufacturing, light industry, furniture manufacturing, coal mining, oil and gas extraction were hit the hardest. The following measures to stabilize the industrial sector are proposed: support for domestic demand for the products of industries, namely metallurgy, machine building, and chemical industry, which are mainly export-oriented and very sensitive to changes in global demand; stimulation and development of high value-added production; acceleration of the digitalization process within national borders; support for the industrial sector in its pursuit of environmentally friendly production, and others.
\end{abstract}

Key words: COVID-19 pandemic, industrial production, economic policy.

JEL Classification: L16, L52, L50, L60, O14, O25

\section{Introduction}

The COVID-19 pandemic has been a serious test for countries around the world. The current global crisis is one of the deepest in 150 years. According to the World Bank, global GDP fell 4.3\% in 2020, U.S. GDP fell 5.4\% and European Union GDP fell 3.6\%, global trade declined by $9.5 \%$. At the same time, China's economy grew by $2 \%$, which reduced the global GDP decline. According to the State Statistics Service of Ukraine, Ukraine's GDP declined by $4 \%$ in 2020. The

Corresponding author:

${ }^{1}$ Kyiv National University of Trade and Economics, Ukraine.

E-mail: 1.lebedeva@knute.edu.ua

ORCID: https://orcid.org/0000-0001-8632-5460

ResearcherID: O-2213-2016

${ }^{2}$ State Higher Educational Institution Kyiv National Economic University named after Vadym Hetman, Ukraine.

E-mail: oleksandra.moskalenko@kneu.edu.ua

ORCID: https://orcid.org/0000-0003-1036-5356

ResearcherID: G-5015-2017

industrial sector also experienced a decline from the effects of the crown crisis, the extent of which will be shown in this article. So now, in a time of economic crisis, it is more important than ever to focus on supporting production, namely the industrial sector, as a source of economic growth. The Industrial Revolution, which originated in Great Britain in the 18th century, gave impetus to the development of the world economy. Thomas Mann stressed the importance of industry, arguing that the development of industry 
would facilitate mutually beneficial foreign trade. William Petty believed that the source of wealth was not trade and exchange, but production, emphasizing the need for government support to stimulate industry. Thus, the importance of the industrial sector cannot be underestimated, since it is the driving force behind modern economic development.

Theoretical basis. Modern research in the field of economic development and, in particular, in the industrial sector has been carried out by the following researchers: Vyshnevsky, V. (2016), Geyets, V. (2015), Gerasymenko, A. (2018) Kindzersky, Y. (2020), Moskalenko, O. (2017), Umantsiv, Iu. (2019) etc. The National Institute for Strategic Studies of Ukraine (2020) assessed the impact of the COVID-19 crisis on the economic development of the country. Recently, there have been many publications highlighting various aspects of the impact of the COVID-19 crisis on economic development, such as: Rose, A. (Rose, 2021) puts the COVID-19 pandemic in perspective, comparing it to other recent disasters in terms of impact on the US macroeconomy; Ya'nan Z., Li F., Xin Zh. et al. (Ya'nan, 2021) consider the spatiotemporal patterns of the effects of COVID-19 controls on industrial production in Wuhan, using a time series of Earth observation data; Humeniuk V. et al. (Humeniuk, 2021) considers conceptual approaches to the interpretation of the features of state financial support for small businesses during the coronavirus crisis; Szczygielski J., Charteris A., Bwanya P. et al. (Szczygielski, 2021) analyze the global impact of COVID-19-related uncertainty on industry returns and volatility; Li L., Peng J., Wu J., Lu Y. (Li, 2021) assess the perceived impact of the COVID-19 crisis on SMEs in various industrial sectors; Lagutin V. et al. (Lagutin, 2020) analyze the institutional conditions for the resilience of the national economy to crisis conditions. Despite considerable attention to this issue, a systematic assessment of the industrial sector in a pandemic and the government's role in minimizing the impact of COVID-19 is needed to mitigate the negative effects of the pandemic on industry and to prepare for future potential shocks.

The aim of the article is to assess the impact of the COVID-19 pandemic on industrial development in Ukraine and the EU, as well as to propose economic policy measures to achieve stabilization in the industrial sector.

\section{The impact of the COVID-19 crisis on Ukraine's industrial sector}

After independence, Ukraine's economy experienced a significant recession, after which it stabilized only in 2000, but the GDP level of 1991 has not been reached. Despite economic stabilization and economic growth in 2000-2007, the global financial and economic crisis of 2008-2009 greatly affected the economy of Ukraine. This shock was primarily caused by the significant raw-material orientation and export dependence of the Ukrainian economy, and therefore vulnerability to fluctuations in world commodity prices, which change greatly during periods of economic instability. Economic growth since 2010 was stimulated by the positive dynamics of prices in foreign markets, but did not bring positive changes in the structure of production of domestic GDP. "The share of industry (B, C, D by NACE) in GDP fell from $45.8 \%$ in 1991 to $17.6 \%$ in 2020 (specifically mining and manufacturing to $14.6 \%)$ ). (State Statistics Service of Ukraine, 2021) Industrial production, especially mechanical engineering, is the basis of the country's economic development, a significant decline in industry has caused the current difficult unstable state of the domestic economy, its raw-material export orientation. By exporting raw materials and semifinished products, Ukraine actually ensures the economic growth of other countries, since the greatest added value is produced in finished products, not in raw materials. For example, in 2019, 24.2\% of the value of Ukrainian merchandise exports were vegetables, ferrous metals $15.6 \%$, and $11.7 \%$ were fats and oils, which together accounted for $51.5 \%$ of export volumes (State Statistics Service of Ukraine, 2021). To overcome this trend, Ukraine needs a strategy of sustainable reindustrialization that will give hope for future economic growth and development.

The industrial sector is important to Ukraine's economy. "In 2020, industry (sectors B, C, D according to NACE) created $17.5 \%$ of the gross value added of the economy, $17.6 \%$ of GDP, $21.5 \%$ of wages, $19.6 \%$ of gross profit of enterprises. There are about 40,000 enterprises involved in the industry" (State Statistics Service of Ukraine, 2021). The industrial sector also provides employment in related industries, such as transport and trade. According to the European Commission, one manufacturing job provides up to two jobs in other industries.

In general, industry in the country is the basis of reproduction of all sectors of the economy through the production of consumer goods and means of production used in agriculture, trade, construction, etc. It is in industry that goods with high added value are produced, which is of great importance for the sustainable development of the economy and the growth of competitiveness of nationally produced goods on world markets.

Ukraine's industry today is influenced by many factors, among which the main ones are:

- the structure of production and the nature of cooperative ties that remained after the collapse of the USSR; 
- the consequences of the failed reforms of the 1990s, when a significant part of the industrial potential, especially high-tech (radioelectronic industry, machine building), was heavily damaged;

- strong dependence on the international market (especially in metallurgy and mining);

- limited and undeveloped demand in the domestic market, particularly for investment products;

- the actual absence of state industrial policy, which would determine the strategic objectives and priorities of industrial development.

Today another factor has been added to these factors - the COVID-19 pandemic. The COVID-19 pandemic has significantly affected economic growth in Ukraine because of existing quarantine restrictions, which were implemented in March 2020. In May 2020, quarantine restrictions were eased. The restrictions included limitations on the entry and movement of people, prohibitions on public transport and inter-regional transportation, a ban on small business activities, a ban on trade, fairs, and also on mass events.

The COVID-19 pandemic has created the following problems for Ukraine's economy and industry:

- the decrease in aggregate global demand and business activity, the reduction of production in the countries of the world, which led to lower prices on world commodity markets. Under these conditions, Ukrainian industrial enterprises incurred losses and reduced the number of employees; metallurgy and machine-building suffered the most. "The decline in demand from world leaders has affected the activities of extractive industries around the world, not just in Ukraine. This caused a decline in the mining industry, as well as in some processing industries (primarily in metallurgy - a decline of $11.7 \%$ in January-October 2020)" (Consequences of the COVID-19 epidemic, p. 9); - strengthening of state regulation (the introduction of a state of emergency, the use of sanitary and epidemiological norms, restrictions on the movement of citizens, distance working and education). Such restrictions have had the greatest impact on internallyoriented industries: transport (primarily aviation), tourism (both external and internal), and other services (food service, sports, art, recreation and entertainment);

- commodity orientation of Ukraine's exports and the significant dependence of industrial enterprises on world commodity prices, with the existing volatility of world markets, which exacerbates the dependence of foreign currency inflows on external price fluctuations; - transport and logistics problems with raw material supply chains due to anti-epidemiological restrictions, reduced production in the processing industry;

- decline in business expectations and reduced investment due to significant uncertainty, which affected the manufacturing industries (a 20.4\% drop in production in mechanical engineering in JanuaryOctober 2020 and a decrease of $8.4 \%$ in the production of construction materials);

The pandemic, however, had not only negative effects, but, on the contrary, had a positive impact on some manufacturing industries, in particular, chemical production showed positive growth (up 6.7\% in January-October 2020) and pharmaceutical production (up 1.0\%) due to high demand for disinfectants and medicines.

Thus, the COVID-19 pandemic has exacerbated existing contradictions in the industrial sector of Ukraine, revealing the most acute problems of its development, such as: Significant dependence on world commodity prices (as the main export items), which makes Ukraine vulnerable to fluctuations in aggregate demand abroad and export revenues; narrow domestic market for national products; export of raw materials with low added value.

The impact of the pandemic on industrial production can be seen in the dynamics of the industrial production index (Figure 1). Due to the limitations of economic activity, transportation problems and a decline in aggregate demand, industrial production in Ukraine fell by $4.5 \%$ per year, with the largest decline coming in April 2020 and amounting to $16.1 \%$. With the easing of quarantine restrictions in May, the decline in industrial production softened to $12.5 \%$. Industrial production resumed in November-December 2020 to the values of the previous year, but with the restrictions associated with the second wave of the coronary crisis, decreased again by $4 \%$ in JanuaryFebruary 2021, resumed in March $2021(+2.1 \%)$ ) and increased even more in April 2021 (+ 13\%) (State Statistics Service of Ukraine, 2021).

The decline in April 2020 was typical for all industrial groups, but the largest declines were in consumer durables by $23 \%$ (to $77 \%$ ), intermediate goods by $17 \%$ (to $83 \%$ ), and capital goods by nearly $15 \%$ (to 86, 6\%) from the base year 2016 (Figure 2). Consumption of consumer durables declined the most, but recovery was fastest after the easing of quarantine restrictions in June $2020(+20 \%)$ and August $2020(+40 \%)$. The situation stabilized in August 2020 with growth in subsequent periods.

The decline in Ukrainian industry began long before the coronavirus crisis and was caused by the negative situation in the markets of the main industrial products for export and a significant imbalance in domestic demand. "In the first five months of 2020, all industries declined except for the chemical industry (up 9.3\%), the pharmaceutical industry (up 6.7\%), and coke and refined oil products production (up 0.2\%)" (State Statistics Service of Ukraine, 2021). High growth rates in the chemical industry were due to the resumption of operation of the PJSC "Odessa Port Plant", as well as favorable conditions for the operation of chemical 
Vol. 7 No. 5, 2021

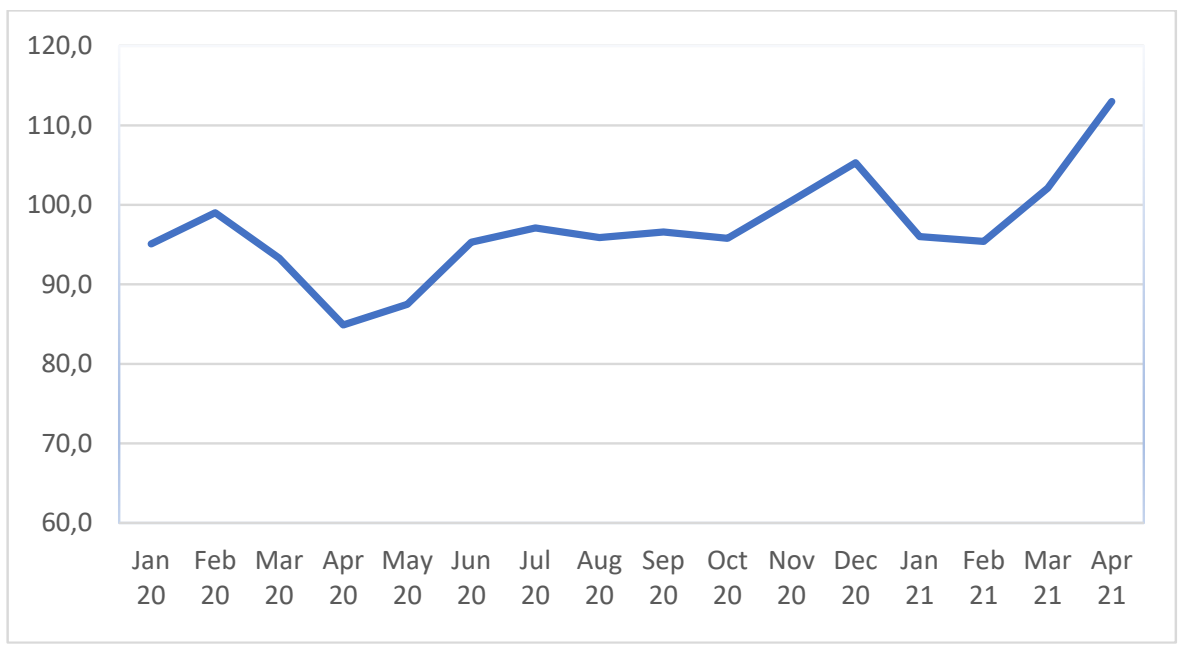

Figure 1. The index of industrial production in Ukraine in Jan. 2020 - Apr. 2021, month-over-month of the previous year

Source: (State Statistics Service of Ukraine, 2021)

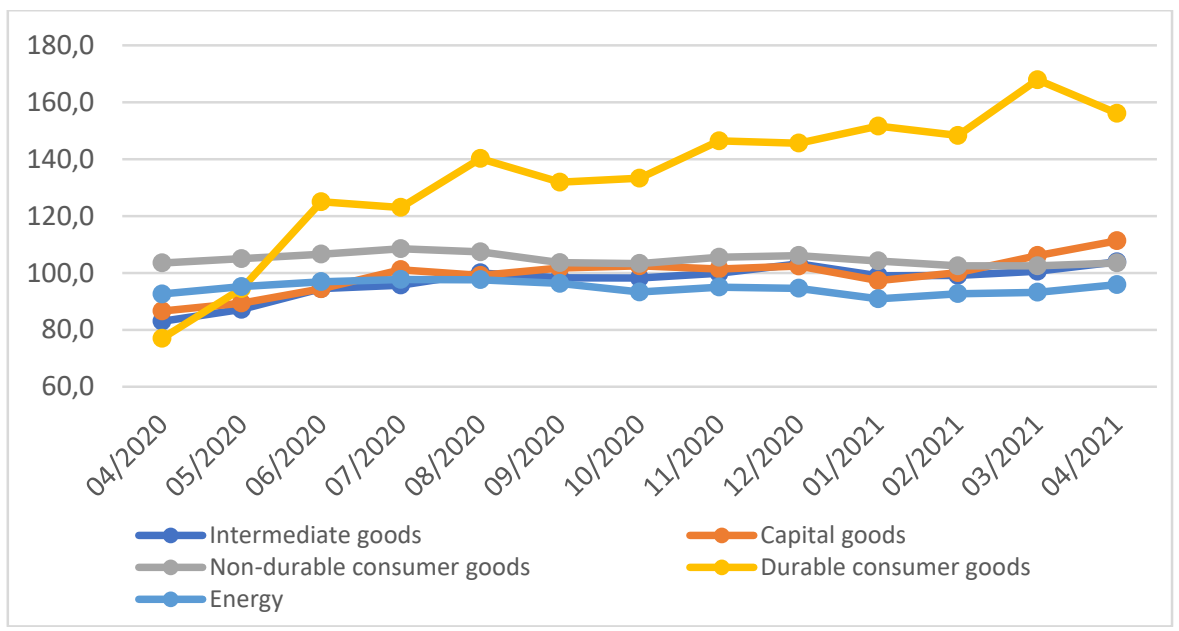

Figure 2. Indices of industrial production in Ukraine by types of activity and main industrial groupings (MIGs)

Source: (State Statistics Service of Ukraine, 2021)

enterprises with cheaper raw materials (natural gas and oil). The pharmaceutical industry experienced growth due to the increased demand for its products with the onset of the pandemic.

"The decline in investment during the pandemic led to a decline in mechanical engineering (-20.2\% in JanuaryMay 2020), and a downturn in metallurgy (-16.1\%), which was caused by a decline in global demand for metal products due to the closure of a large number of auto plants in the EU, significant protectionist restrictions on exports of domestic metal products to the EU, the US, Eurasian Economic Area, India, Pakistan, Egypt, Canada, etc." (Ukraine after the coronavirus crisis, 2020, p. 41). In addition, the situation was significantly complicated by the introduction of restrictions on imports to the EU; logistical problems of iron and steel enterprises due to frequent interruptions of deliveries by state transport companies and seaports.

In spite of a significant decrease, there was a significant growth in some positions in the engineering industry. Thus, the production of radiological, electromedical and electrotherapeutic equipment increased by 1.34 times (which is the result of growth in demand). Production of batteries and accumulators (1.2 times), production of electric lighting equipment (1.03 times), production of household appliances (1.2 times) also increased (State Statistics Service of Ukraine, 2021). The increase in production of these products is due to a change in lifestyle during the pandemic (self-isolation pushes self-sufficiency, including kitchen appliances). In the structure of mechanical engineering, these 
products accounted for only 5\% and therefore did not have a significant impact on the overall picture.

During the March-May 2020 quarantine, production fell sharply in all industries, but the food industry was the least affected, the pharmaceutical industry was positive, and the chemical industry slowed after March before falling in May 2020.

The coronavirus crisis affected industrial enterprises regionally in Ukraine rather unevenly. Most enterprises did not stop working during the quarantine period, adapting to the requirements and carrying out antiepidemic measures and organizing the transportation of workers. In Transcarpathian region during the quarantine many enterprises suffered losses in the automotive and electronics industries (LLC "Jabil", CJSC "Eurocar", LLC "Yazaki Ukraine", LLC "Ungweier"), woodworking industry (LLC "Sio-K", LLC "Wood-working Industry", LLC "Samver"), which reduced production by half. This reduction was caused by a drop in demand from EU countries and a shortage of components. At the same time, employees were sent on vacation or part-time. "Exporting companies in Lviv, Volhynia and Zhytomyr regions have reduced production, depending entirely on orders from parent companies, most of which are in the European Union, due to the decline in demand for cars. The companies Bader, Leoni, Bordnetse, Fujikura, Kromberg \& Schubert resumed operations from the beginning of May 2020, their production capacity not exceeding $70 \%$ compared to the previous year" (Ukraine after the coronavirus crisis, 2020 , p. 68-70).

A critical situation has developed in the field of coal mining, as the crown crisis has effectively shut down coal production in Ukraine. In AprilMay 2020, DTEK "Pavlograd Coal" and DTEK "Dobropolyevugol", which accounted for 95\% of coal production in Ukraine (excluding production in the temporarily occupied territories) and employed over
40,000 people, suspended their operations" (Ukraine after the coronavirus crisis, 2020, p. 68-70).

\section{The impact of the COVID-19 crisis on the industrial sector in the $\mathrm{EU}$ and the world}

The COVID-19 pandemic has affected all countries in the world, consider what methods have been used in the EU to combat the pandemic. To combat the pandemic, EU member states used various measures, including restrictions on entry and movement between member states, a ban on public events, restrictions on private gatherings, closures of schools, bars, restaurants, hotels, and more. In Italy and Spain, non-critical areas of production were halted, but the measures imposed had an overall negative impact on demand and, consequently, on production in many areas. The vast majority of preventive measures were introduced in mid-March and continued through April 2020. In May, EU countries introduced some easing of restrictions, which contributed to the resumption of industrial production.

Due to the restriction of business closures, industrial production fell $10.1 \%$ in March and $18.6 \%$ in April 2020 in the EU, recovering in May (+12.0\%), June $(+9.5 \%)$, and July $(+4.6 \%)$. Overall, industrial production in February 2021 was $99.0 \%$ of what it was a year earlier (Eurostat, 2021).

Industrial production in the European Union declined significantly during the coronavirus crisis (Figure 3). The index of industrial production as a whole fell by $23.7 \%$ to $76.7 \%$ in April 2020 . By major industrial groups, the largest decline was in: consumer durables (like household appliances, furniture) a decrease of $44.3 \%$, investment goods (e.g., transport equipment, computers) (-37.6\%), intermediate goods (e.g., raw materials) decreased by $20 \%$, energy production by $13.3 \%$. Production of consumer

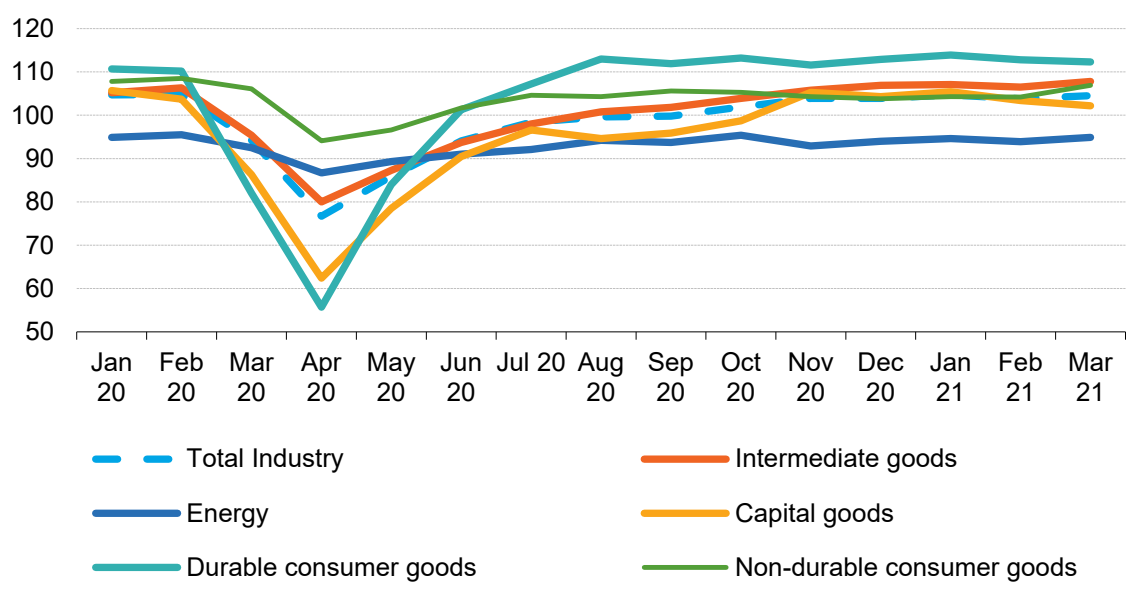

Figure 3. EU Industrial Production Index, January 2020 - March 2021, to base year (2015) Source: (Eurostat, 2021) 
durables (e.g., food, clothing) declined the least, by $5.9 \%$ (Eurostat, 2021).

In March 2021, industrial production in the EU increased by $0.6 \%$ compared to the previous month; in the Eurozone, industrial production increased by $0.1 \%$ with a further positive trend.

As for the crisis in EU industry, in 2020 there was a decline in production in all industries, most of all in: the automotive industry $(-83 \%)$, leather $(-79 \%)$, light industry $(-68 \%)$, furniture $(-52 \%)$, coal, oil and gas extraction $(-50 \%)$. An increase of $32 \%$ was observed in the pharmaceutical industry (Eurostat, 2021).

Regarding the recovery, the European Parliament estimates that "industries such as the chemical, construction, and food and beverage sectors are likely to experience a $\mathrm{V}$-shaped recovery from the crisis. Despite the initial shocks, the automobile and textile industries seem to be on the road to recovery from the initial closures. Sectors that depend on human contact and interaction, such as the cultural and creative industries and the aerospace industry (due to declining mobility and tourist activity), have been hit hard by the crisis, and they are likely to suffer for a long time from these unprecedented shocks" (de Vet, 2021, p. 8).

The coronavirus pandemic affected EU countries in different ways. Since the measures to contain COVID-19 differed across the EU in terms of the timing and severity of restrictions, it is clear that the impact on the level of industrial production was different. "During the peak months of the crisis (February 2020 - April 2020), Italy, Slovakia, Cyprus and Hungary experienced extremely high rates of decline. These countries also showed high rates of recovery in May 2020. In some other countries, the crisis had a rather small effect on industrial production: between February and April 2020, production rose in Ireland by $6.4 \%$, and in Finland by $0.2 \%$. In most countries, however, the rate of industrial production (recession) was about - 25\%" (Eurostat, 2021).

In Wuhan, China, the coronavirus crisis had this effect on industrial production: during the year, industrial production was lower than expected, with a $14.30 \%$ drop; the most serious effect of COVID-19 on industrial production was seen in March and April 2020, then, after the lockdown was lifted, some regions (approximately $4.90 \%$ ) initially returned to expected levels in June, and almost all regions (98.49\%) completed the resumption of work and production through November 2020 in Wuhan, China (Zhou, 2021).

Globally, based on an analysis of the impact of uncertainty associated with COVID-19 on industry returns and volatility, it was shown that "uncertainty associated with COVID-19, as measured by the aggregate Google search volume index, has a persistent negative impact on industry returns and a positive impact on return volatility. The least impacted industries are those associated with the provision of goods and services that can be viewed as necessities and substitutes (in the days of COVID-19). Prominent examples are food and basic goods retailing, household goods, and telecommunications. Industries such as energy, consumer credit and air travel are the most negatively impacted, which may reflect the negative impact of COVID-19 on global economic growth and confidence, as well as the impact of related blockchains and restrictions" (Szczygielski, 2021).

\section{Economic policy measures to stabilize the industrial sector of the economy}

The European Parliament makes recommendations such as recovery measures and policies in the COVID-19 crisis:

1) "ensure that national recovery and sustainability plans address the specifics of industrial fabrics: there is no "one-size-fits-all" solution;

2) national recovery and resilience plans should go beyond recovery to pre-crisis levels and should focus on improving the competitiveness of EU industry through investment in $\mathrm{R} \& \mathrm{D}$ and digital retraining/upskilling;

3) maintain strategic value chains in which Europe can have a competitive advantage, rather than dealing with potential short-term disruptions;

4) to ensure sustainability, national and EU measures must support diversification of access to critical raw materials;

5) include investment in the circular economy in national recovery plans and provide the necessary regulatory changes to reduce pressure on value chains; 6) address the problem of multiple goals in national recovery and resilience plans by prioritizing them;

7) accelerate the adoption of national recovery and resilience plans to avoid further widening the gap with other leading economies;

8) make sure national recovery and sustainability plans have genuine European character and oversight" (de Vet, 2021, p. 9).

The impact of the pandemic has highlighted and further exposed Ukraine's industrial weaknesses.

1. Ukrainian industry develops haphazardly and uncoordinatedly between different types of economic activity. For example, Ukraine actively exports iron ore, titanium raw materials, and rare earth minerals, such as lithium, niobium, and tantalum, which are in short supply on the world market. At the same time in the structure of imports there are machines, equipment, instruments, microelectronics, other high-tech products that could be produced within the national borders in the presence of raw materials and still high enough scientific and technological potential 
of Ukraine. The pandemic has shown that the global economic crisis caused by it further strengthens the raw material orientation of Ukrainian industry and the gap between highly developed countries that have overcome the crisis with the help of new technologies and third world countries is widening.

2. To overcome these negative trends, an active state economic and industrial policy is needed that will support national innovative manufacturers.

Recommendations to change the approach to the development of industrial policy in Ukraine, taking into account the consequences and lessons of the pandemic period.

1) Supporting domestic demand for the products of industries, namely metallurgy, engineering, and the chemical industry, which are mainly export-oriented and very sensitive to changes in global demand, as well as promoting a policy of export diversification. Due to the reduction of investments by European partners, strengthening of protectionist policies and increased competition on export markets, a further decrease in demand for the main components of Ukrainian industrial exports will be observed, it should be expected that industrial production in exportoriented sectors will decrease in the future and tax and currency revenues will decrease accordingly.

2) Stimulation of processing in the food industry and development of industries with high added value. External demand for food products will remain stable and grow. However, the growing presence of Ukrainian food products on world markets is currently constrained by an insufficient share of deeply processed goods and a focus on raw material exports. Under such conditions, even a significant increase in exports will not provide a qualitative change in its structure and the necessary growth rate of foreign exchange earnings, so it is necessary to maintain the production of processed goods in the structure of Ukraine's exports.

3) Conduct a systematic structural policy that will ensure the consistent development of domestic industry and get rid of the raw material model of the economy.

4) It is necessary to reverse the trend of international specialization of Ukraine, according to which in the structure of exports more than two-thirds are raw materials and low-tech products, and in the structure of imports - on more advanced processing goods.

5) Support of the national production and investment infrastructure based on the introduction of new technologies. The global trend in the context of the coronavirus pandemic to localize production chains within national borders will increase the stability of national supply chains and minimize dependence on external partners. In addition to the decline in demand for Ukraine's intermediate products, this threatens a significant reduction in foreign investment in industry.
The answer to these risks should be an intensification of efforts to form Ukraine's own national economic ecosystems by developing investment infrastructure and financial support for regional specialization. Priority for specialization should be given to industries that will ensure the economic security of the state - food, chemical, pharmaceutical, engineering. Efforts should be aimed at strengthening the innovative potential of the research sector, its ability to generate new methods of combating modern threats of the coronavirus crisis, etc.

6) Support the process of digitalization within national borders. The digital component of the domestic and global competitiveness of industrial enterprises will be strengthened. In the face of severe quarantine measures and transportation restrictions during the pandemic, the viability of many industries was directly proportional to the level of automation and digitalization of production and management processes. The transition of transactions to the digital space will continue at an accelerated pace. Therefore, state support measures for the development of digital infrastructure in the industrial sector will be relevant. "As the best global experience shows, the structural policy in the industry of Ukraine should be dualistic in its content and form - combine the tools of both "vertical" ("sectoral") and "horizontal" ("institutional") models of such a policy. The tools of the "vertical" model should be used to change the structure of production, its technological modernization and creation of new productions mainly on the basis of large-scale technological borrowings. At the same time activation of entrepreneurial and innovative activity of subjects should be achieved with the help of tools of the "horizontal" model of policy" (Kindzerskyi, 2020, p. 112).

7) It is necessary to strengthen state financial and institutional support of national producers. With the growth of protectionist measures in the world, the variety of instruments for supporting domestic producers (state guarantees, tax, credit, customs preferences, export support, subsidies, etc.) gives undeniable advantages in overcoming the consequences of the coronavirus crisis.

8) Supporting the industrial sector in its pursuit of environmentally friendly production. Environmental standards and EU requirements will become a real obstacle for Ukrainian exporters in the near future. Thus, the "European Green Deal" involves the transition to a carbon-neutral economy by 2050 and the introduction of import duties on products with high carbon emissions (border tax on carbon) to protect domestic producers and prevent the export of environmentally polluting industries abroad. Thus, the prospects for Ukrainian products in foreign markets will largely be determined by the amount of investment in ecomodernization, resource saving and decarbonization of industry. 


\section{Discussion}

The coronavirus crisis pandemic has had a huge impact on economies around the world, it is said to have had even greater consequences than the 2008-2009 crisis. Governments therefore need to respond urgently to the consequences of this crisis and ensure that their economies are sustainable in the future. This requires using the lessons of the current crisis to make economies more resilient to future shocks. Some measures for stabilization in the industrial sector of Ukraine, which can be implemented, are proposed. They can be used for further discussion and improvement of the country's economic policy.

\section{Conclusions}

The COVID-19 pandemic has exacerbated existing contradictions in Ukraine's industrial sector, exposing its most acute development problems, such as significant dependence on world raw material prices (as the main export item), which makes Ukraine vulnerable to fluctuations in aggregate demand abroad and income from exports; narrow domestic market; export of raw materials with low added value; insufficient investment for future development. Due to restrictions on economic activity, transportation problems, and a decline in aggregate demand, industrial production in Ukraine declined by $4.5 \%$ in 2020, with the largest decline occurring in April 2020 at $16.1 \%$. Most Ukrainian enterprises did not stop working during the quarantine period, adapting to the requirements and implementing antiepidemic measures and organizing the transportation of workers.

In the European Union, industrial production is down 10.1\% in March 2020 and 18.6\% in April 2020 due to constrained business activity. The decline in production in 2020 was observed in all industries, most of all in: automobile industry $(-83 \%)$, leather $(-79 \%)$, light industry $(-68 \%)$, furniture production $(-52 \%)$, mining of coal, oil and gas $(-50 \%)$. The growth of $32 \%$ was observed in the pharmaceutical industry. The crisis caused by the coronavirus hit the industrial sectors of Italy, Slovakia, Cyprus and Hungary the hardest, while Finland and Ireland were the least affected, growing by $6.4 \%$.

Thus, the coronavirus crisis has had a strong impact on industrial production in both Ukraine and the European Union. The fall in industrial production in the spring of 2020 in the EU was about 19\%, in Ukraine $16 \%$, as of April 2021 EU industry has recovered to precrisis levels, the national industry of Ukraine has grown by $13 \%$ (by April 2020), which did not compensate for the fall in 2020 .

Measures to stabilize the industrial sector in Ukraine include the following: supporting domestic demand for the products of industries, namely metallurgy, engineering, chemical industry, which are mainly export-oriented and very sensitive to changes in global demand, as well as promoting a policy of export diversification; stimulate processing in the food industry and the development of industries with high added value; pursue a systematic structural policy that will ensure the consistent development of domestic industry and the abandonment of the raw materials model of the economy; It is necessary to reverse the trend of international specialization of Ukraine, according to which in the structure of exports more than two-thirds are raw materials and low-tech products, and in the structure of imports - more advanced processing goods; make sure that the development of national industrial and investment infrastructure is based on the implementation of new technologies; accelerate the process of digitalization within national borders, because when strict quarantine measures and transport restrictions were imposed during the pandemic, the viability of many industries was directly proportional to the level of automation and digitalization of production and management processes; supporting the industrial sector in its pursuit of environmentally friendly production, as environmental standards and EU requirements will become a real obstacle for Ukrainian exporters in the near future.

\section{References:}

de Vet, J. M., et al. (2021). Impacts of the COVID-19 pandemic on EU industries, Publication for the committee on Industry, Research and Energy, Policy Department for Economic, Scientific and Quality of Life Policies, European Parliament, Luxembourg.

Consequences of the COVID-19 epidemic and quarantine measures for the leading sectors of the Ukrainian economy (2020). Research based on the results of indepth interviews with owners and top managers of Ukrainian companies. Kyiv-Kharkiv: Publisher Miroshnychenko, O.

Gerasymenko, A., \& Afendikova, S. (2018). The relevant temporal market definition in antitrust analysis. Baltic Journal of Economic Studies, 4(1), 68-76. DOI: https://doi.org/10.30525/2256-0742/2018-4-1-68-76

Heiets, V. M. (2015). Barriers to the development of industry on an innovative basis and opportunities to overcome them. Economy of Ukraine, 1, 4-25.

Humeniuk V., et al. (2021). State financial support for small business during the coronavirus crisis in European countries. Financial and Credit Activity: Problems of Theory and Practice, 3(38), 326-332.

Kindzerskyi, Y. (2020). The policy of inclusive and sustainable industrialization in Ukraine: challenges and priorities for implementation. Economic analysis, 30(1), 105-117. 
Lagutin, V., Boiko, A., \& Shkuropadska, D. (2020). Institutional conditions for ensuring resilience of national economy: on the example of Ukraine. Baltic Journal of Economic Studies, 6(3), 76-86. DOI: https://doi.org/ $10.30525 / 2256-0742 / 2020-6-3-76-86$

Li, L., Peng, J., Wu, J., et al. (2021). Perceived impact of the Covid-19 crisis on SMEs in different industry sectors: Evidence from Sichuan, China. International Journal of Disaster Risk Reduction, 55.

Moskalenko, O. M. (2017). Neoliberal logics of the austerity policies in Ukraine: the relationship with innovative growth. Scientific Bulletin of Polissia, 4(12), 28-35.

Official site of the State Statistics Service of Ukraine (2021). Available at: http://www.ukrstat.gov.ua (accessed October 15, 2021).

Official website of Eurostat (2021). Available at: http://ec.europa.eu/eurostat/web/structural-business-statistics/ data/main-tables (accessed October 15, 2021).

Szczygielski, J., Charteris, A., Bwanya, P., et al. (2021). The impact and role of COVID-19 uncertainty: A global industry analysis. International Review of Financial Analysis.

Zhalilo, J. (ed.) (2020). Ukraine after the coronavirus crisis - the path to recovery. Kyiv: National Institute for Strategic Studies.

Umantsiv, Iu., Lebedeva, L., \& Mitrofanova, A. (2019). Modern trends in governance of state ownership relations. Baltic Journal of Economic Studies, 5(5), 155-164. DOI: https://doi.org/10.30525/2256-0742/2019-5-5-155-164 Vyshnevsky, V. P. (2016). National model of neoindustrial development of Ukraine. Kyiv: Institute of economy and industry of Ukraine.

World Bank Review of Global Economic Prospects (GEP) (2021). Available at: https://www.worldbank.org/en/ publication/global-economic-prospects (accessed October 15, 2021).

Ya'nan Zhou, Li Feng, Xin Zhang et al. (2021). Spatiotemporal patterns of the COVID-19 control measures impact on industrial production in Wuhan using time-series earth observation data. Sustainable Cities and Society, 75. 